\title{
DCLRE1B wt Allele
}

National Cancer Institute

\section{Source}

National Cancer Institute. DCLRE1B wt Allele. NCI Thesaurus. Code C91862.

Human DCLRE1B wild-type allele is located in the vicinity of 1 p13.2 and is approximately 9 $\mathrm{kb}$ in length. This allele, which encodes DNA cross-link repair 1B protein, plays a role in the repair of DNA crosslinks. 